\title{
A Case Study on Rent Pricing of Financial Leasing of Photovoltaic Enterprises Taking Henan Yicheng New Energy Co., Ltd. as an example
}

\author{
Changhui Yang ${ }^{1,}{ }^{*}$, Jingjing Liu ${ }^{2}$ \\ ${ }^{1}$ Doctor, School of Management, Hefei University of Technology, China \\ ${ }^{2}$ Master, School of Management, Hefei University of Technology, China
}

\begin{abstract}
Photovoltaic power generation industry, as a strategic emerging industry with heavy assets in China at present, the contradiction between the gradual reduction of policy subsidies and the rapid expansion of installed capacity of the industry is becoming more and more acute. Under the background of tightening bank intervention policy and insufficient matching of funds, China's photovoltaic industry is generally faced with financing difficulties, and its development is slow and urgent. At present, financial leasing has become the second largest financing option for distributed photovoltaic manufacturers except bank loans. The purpose of this paper is to study how to revitalize the existing capital and optimize the capital structure by means of financing sale and leaseback, and try to discuss the rental pricing scheme by measuring the financial leasing cost of photovoltaic power plans.
\end{abstract}

\section{Introduction}

With the continuous development of the global economy, the demand for energy is increasing rapidly. However, coal, oil, natural gas, etc. all belong to one-time nonrenewable conventional energy, which cause irreversible damage to ecological environment and seriously endanger the sustainable development of global economy and human life and health. At present, the intensive economic model based on renewable energy has become the way of future. According to China's commitment to the world, the proportion of non-fossil energy in China will reach $20 \%$ by 2030 . As the clean energy of new energy, photovoltaic power generation has been strongly supported by the national policies. During the "Thirteenth Five-Year Plan" period, the investment of new energy industry will be increased by about 2 trillion yuan, while the newly installed capacity of photovoltaic and wind power accounts for about $90 \%$ of the total installed capacity of new energy, with the largest room for growth. By the end of 2019, the cumulative installed capacity of wind power and photovoltaic power generation in China has reached 210 million kilowatts and 204 million kilowatts respectively, and the total subsidy budget for new photovoltaic power generation projects in 2020 is 1.5 billion yuan. ${ }^{[1]}$ Among them: 500 million yuan is used for household photovoltaics, subsidizing bidding projects (including centralized photovoltaic power stations and industrial and commercial distributed photovoltaic projects), and organizing project construction according to the total subsidy of 1 billion yuan.
While the prospect of photovoltaic industry is promising, the industry lands itself in trouble of financing difficulties. In 2013, China's National Energy Administration and the United Nations Development Bank issued the Opinions on Supporting Financial Services for Distributed Photovoltaic Power Generation, which required that photovoltaic enterprises, especially distributed photovoltaic power stations, should be actively supported to alleviate the financing difficulties and then the situation began to improve. At present, in addition to the cash flow brought by its own funds and state subsidies, the financing methods of photovoltaic industry mainly include bank project loans and financial leasing. Even for listed companies with strong financing ability, there is still a large financing gap for the capitalintensive new energy power station development business, so it is necessary to continue to leverage funds and strive to obtain more high-quality power stations during the investment window of new energy power stations. Due to the long construction period of photovoltaic power station, the huge demand for initial capital and the uncertainty of the expected return on investment of photovoltaic power station, it is difficult for photovoltaic industry to obtain funds through the traditional financing channel of bank credit project loan. According to the "Thirteenth Five-Year Plan for Solar Energy Development" (hereinafter referred to as the "Plan") issued by the state, the installed capacity of photovoltaic power generation in China will reach about 110 million KW by the end of 2020. According to the construction cost of photovoltaic power station in 5 yuan $/ \mathrm{W}$, the required capital is 550 billion yuan. It needs a lot of money to achieve the target set by the Plan, which

\footnotetext{
* Corresponding author: yangchanghui@hfut.edu.cn
} 
requires not only mature markets but also various financing methods. As a widely used financing method at present, the financial leasing mode takes the cash flow of the leased property (equipment) in the future as the repayment guarantee, and the financial leasing usually provides medium and long-term financing, with a term of more than 5 years, which can well meet the financing needs of photovoltaic new energy industry with large amount and long cycle, and has a significant fit with the financing needs of photovoltaic power generation enterprises. The lessee can make use of the cash flow regularly obtained from the sale and leaseback to make venture capital investment in other projects to obtain profits. Taking photovoltaic power plants as leases can not only ensure long-term stable cash flow, but also have a significantly higher return on investment than traditional thermal power assets. The comparison between bank credit financing and financial leasing is shown in Table 1.

Table 1. Comparison of two financing methods: financial leasing and direct leasing

\begin{tabular}{|c|c|c|}
\hline $\begin{array}{l}\text { FINANCIN } \\
\text { G MODE }\end{array}$ & BANK CREDIT & $\begin{array}{l}\text { FINANCE } \\
\text { LEASE }\end{array}$ \\
\hline $\begin{array}{l}\text { Financing } \\
\text { Access } \\
\text { Threshold }\end{array}$ & $\begin{array}{c}\text { Higher credit } \\
\text { requirements for } \\
\text { enterprises; Higher } \\
\text { access threshold; Not } \\
\text { conducive for SMEs } \\
\text { to apply for project } \\
\text { loans }\end{array}$ & $\begin{array}{l}\text { Relatively loose } \\
\text { credit } \\
\text { requirements for } \\
\text { enterprises; Lower } \\
\text { access threshold; } \\
\text { Easier for SMEs to } \\
\text { obtain financing }\end{array}$ \\
\hline $\begin{array}{l}\text { Approval } \\
\text { Time }\end{array}$ & $\begin{array}{c}\text { More cautious } \\
\text { approval process; } \\
\text { Many functional } \\
\text { departments need to } \\
\text { approve at different } \\
\text { levels; Cumbersome } \\
\text { steps and longer } \\
\text { approval time }\end{array}$ & $\begin{array}{c}\text { Simple approval } \\
\text { process; Faster } \\
\text { procedures; } \\
\text { Shorter application } \\
\text { time }\end{array}$ \\
\hline $\begin{array}{l}\text { Financial } \\
\text { Stability }\end{array}$ & $\begin{array}{l}\text { Facing an another } \\
\text { approval after a short } \\
\text { credit period; The } \\
\text { risk of breaking the } \\
\text { capital chain }\end{array}$ & $\begin{array}{l}\text { Good financial } \\
\text { stability; No risk } \\
\text { of capital chain } \\
\text { breakage }\end{array}$ \\
\hline $\begin{array}{c}\text { Subsequent } \\
\text { Repayment } \\
\text { environme } \\
\text { nt }\end{array}$ & $\begin{array}{c}\text { Strict repayment } \\
\text { conditions; The risk } \\
\text { of losing reputation } \\
\text { at any time }\end{array}$ & $\begin{array}{c}\text { Flexible } \\
\text { repayment } \\
\text { form;The lessee } \\
\text { and the lessor can } \\
\text { agree on } \\
\text { adjustment }\end{array}$ \\
\hline $\begin{array}{l}\text { Financing } \\
\text { difficulty }\end{array}$ & $\begin{array}{l}\text { Higher, not suitable } \\
\text { for small and } \\
\text { medium-sized } \\
\text { enterprises }\end{array}$ & $\begin{array}{l}\text { Applicable to any } \\
\text { enterprises }\end{array}$ \\
\hline
\end{tabular}

\section{Review and arrangement of relevant literature}

Sharp(1996) concluded that financial leasing can effectively replace direct loan financing through empirical analysis. Zhou Guangyan (2002) and others said that the development and innovation of financial leasing mode has a great impact on solving the financing problems of high-tech enterprises, and at the same time can effectively alleviate the tense situation of insufficient funds in China's scientific research system, and provide corresponding financial support for the rise and establishment of high-tech enterprises and the development of scientific research institutions. Guo Tao (2003) thinks that financial leasing has the advantages of low threshold and prolonging financing period, and should vigorously develop the financing mode of financial leasing to become the main financing mode for SMEs. Lu Zhenyu (2014) thinks that high-tech equipment or patent right, which is the main asset of high-tech enterprises, can not only realize financial financing for high-tech enterprises, but also effectively control the actual use direction of investment funds, improve the effectiveness of enterprise investment, enhance the binding force on enterprises and effectively reduce risks. He Ze (2018) analyzed that enterprises with high share of fixed assets are more inclined to choose financial leasing mode by combining theoretical assumptions with empirical research methods. Wang Taozhe (2019) believes that financial leasing can combine financing and financial integration, and alleviate the financing pressure of enterprises. Improve the value judgment and risk control means of photovoltaic power plant enterprises, and make the financing mode of photovoltaic power plant enterprises more in line with the market. At the same time, it is also beneficial for both parties to establish a long-term and stable cooperative relationship.

The financing data of photovoltaic power station projects in China from 2015 to 2019 are shown in the following figure:

Table 2. Data on lease financing of photovoltaic power station projects in 2015-2019

\begin{tabular}{|c|c|c|c|}
\hline Year & $\begin{array}{c}\text { Number of } \\
\text { Financing } \\
\text { Transactions }\end{array}$ & $\begin{array}{c}\text { Total } \\
\text { financing } \\
\text { amount } \\
\text { (RMB) }\end{array}$ & $\begin{array}{c}\text { Average } \\
\text { amount of } \\
\text { financing } \\
\text { (RMB) }\end{array}$ \\
\hline 2015 & 7 & 81000,0000 & 115714300 \\
\hline 2016 & 43 & 7092594000 & 164944100 \\
\hline 2017 & 37 & 6452401000 & 174389200 \\
\hline 2018 & 110 & 11013610000 & 100123700 \\
\hline 2019 & 7 & 2126581000 & 303797300 \\
\hline
\end{tabular}




\section{Research on Pricing Model and Case Data of Financial Leasing Products after Sale and Lease-back}

\subsection{Basic model of rent pricing discount}

The factors that need to be considered in the pricing scheme of financial leasing products usually include the principal, security deposit, handling fee, insurance premium, leasing rate, calculation method of leasing rate, leasing period, rent payment amount per period, rent payment interval, rent payment time per period, rent payment method and nominal price. ${ }^{[7]}$ In the pricing contract of financial leasing products, the lessor and lessee shall jointly negotiate and determine other influencing factors besides the principal of financial leasing after considering their own risks and benefits. At present, the methods of calculating financial lease amount usually include equal annuity method and average capital method. Among them, after subdivision, it can be divided into four ways: equal annuity method with rent paid first, equal annuity method with rent paid later, average capital method with rent paid first and average capital method with rent paid later. In practice, the equal annuity method which usually pays rent later occupies the majority, so this paper will discuss this repayment method, and the other three methods will not be repeated. Based on the above factors, the basic form of the discount model of rental pricing for financial leasing is shown in Formula (1):

$$
P V A_{n}=A \sum_{t=1}^{n} \frac{1}{(1+i)^{t}}
$$

Among them, $\mathrm{PVA}_{\mathrm{n}}$ represents the present value of all rents obtained by the lessor; A represents the rent that the lessee needs to pay to the lessor in each period, that is, every year, including the principal and interest shared in the current period; $\mathrm{N}$ represents the number of interest-bearing periods; $\mathrm{T}$ stands for interest-bearing period; I stands for interest rate. Considering that financial leasing enterprises have certain profitability factors to consider, the interest rate I should also consider the liquidity risk reward of inflation compensation, default risk reward, opportunity cost and other factors in the actual transaction, and consider the risk reward within the equipment lease period, so I is a multi-dimensional value.

\subsection{Scope conditions that rent pricing needs to meet}

On the one hand, as far as the lessor is concerned, in addition to the direct expenses such as cost (C), transaction cost $(\mathrm{Ct})$ and tax $(\mathrm{T})$ incurred when acquiring the leased object, it is also necessary to consider the factors such as the security deposit $(\mathrm{Cd})$, regular rent $(\mathrm{R})$, insurance premium $(\mathrm{Ci})$, lease term, lease rate and equipment residual value recovery and realization present value (NP), etc. Therefore, the present value of the total income obtained by the lessor must meet the following conditions (2):

$$
P V A_{n} \geq C+C_{t}+T+C_{i}-N P
$$

On the other hand, as far as the lessee is concerned, the main factors to be considered in the pricing process of financial leasing products are the lessee's operating cash inflow, operating cash outflow, turnover tax and income tax, depreciation period and depreciation amount of assets. 8 Therefore, the present value of the total cash flow paid by the lessee shall meet the following conditions (3):

$$
P V A_{n} \leq(X R-X C)(1-m)-(X R-X C-V A T-D) \times I_{t}(3) .
$$

Among them, XR represents the present value of the lessee's operating cash inflow; XC indicates the cash flow occurrence value of lessee's operation; $\mathrm{M}$ stands for transfer tax rate; VAT stands for vat; D represents the depreciation present value of equipment; It stands for income tax rate.

\subsection{Profit consideration for rent pricing model}

This paper will introduce IRR to further determine the range of rent pricing through profit level.

$$
\sum_{t=1}^{n} \frac{N C F_{t}}{(1+r)^{t}}-\left(C+C_{t}+T+C_{i}-N P\right)=0
$$

Among them, NCFt represents the net cash flow in the $t$ year; $\mathrm{R}$ represents the internal rate of return; $\mathrm{N}$ indicates the service life of the project.

\section{Research on Case Data of Rent Pricing of Financial Leasing Project}

\subsection{Calculation of data related to equipment leasing}

Henan Yicheng New Energy Co., Ltd. is a listed enterprise with mixed ownership dominated by new materials, new energy, energy conservation and environmental protection. Its actual controller is the State-owned Assets Supervision and Administration Commission of Henan Province. The energy conservation and environmental protection industry of the company has begun to take shape. Up to now, the company has built and put into operation several photovoltaic power plants in Henan, Xinjiang and Inner Mongolia. Therefore, its project data has certain industry representativeness. In this paper, we will take a financial leasing business of Yicheng Xinneng Company as an example. The leased property in this transaction is a set of solar power plant components. 
Table 3. Basic information of the subject matter of the transaction.

\begin{tabular}{|c|c|c|}
\hline $\begin{array}{c}\text { Name of } \\
\text { Leasehold }\end{array}$ & $\begin{array}{c}\text { Quantity and } \\
\text { quantity unit }\end{array}$ & Price \\
\hline $\begin{array}{c}\text { The solar battery } \\
\text { component }\end{array}$ & 1 unit & 100 million \\
\hline
\end{tabular}

The current formula of contract data related to lease agreement is shown in Table 4:

Table 4. Relevant Data of Project Financing Lease.

\begin{tabular}{|c|c|c|c|}
\hline $\begin{array}{c}\text { Amount of } \\
\text { Financial lease } \\
\text { contract }\end{array}$ & $\begin{array}{c}100 \\
\text { million }\end{array}$ & $\begin{array}{c}\text { Term of } \\
\text { Lease }\end{array}$ & 2.5year \\
\hline $\begin{array}{c}\text { Lease Annual } \\
\text { Interest Rate }\end{array}$ & \multicolumn{2}{|c|}{ Sale Leaseback } \\
\hline Lease mode & $\begin{array}{c}\text { This financial leasing business is } \\
\text { divided into 10 periods; Pay once } \\
\text { every three month; During the } \\
\text { lease term, the rent shall be repaid } \\
\text { at the amount agreed by both } \\
\text { Payment } \\
\text { Method }\end{array}$ & $\begin{array}{c}\text { parties, and the rent shall be paid at } \\
\text { the end of each period. }\end{array}$ \\
\hline $\begin{array}{c}\text { Ownership of } \\
\text { leased } \\
\text { equipment }\end{array}$ & $\begin{array}{c}\text { During the lease period, the } \\
\text { ownership of the equipment } \\
\text { belongs to Ping An Leasing } \\
\text { lease contract is fulfilled, the } \\
\text { Company will pay the nominal } \\
\text { price (RMB 100 yuan) for the } \\
\text { reserved purchase and return the } \\
\text { ownership of the leased equipment } \\
\text { to the Company. }\end{array}$ \\
\hline
\end{tabular}

According to the above model equation, the rent after each period including principal and interest can be calculated by Excel as 10,743,134.59 yuan; Among them, the interest rate I is $1.325 \%$ per period, with 10 periods in total. Since the subsidy usually lasts for 20 years, this paper assumes that the depreciation period of equipment is 20 years, and the residual value rate is $5 \%$. If the depreciation amount of equipment is 250,000 yuan per year, the depreciation of equipment will be 62,500 yuan per quarter. Since 2013, the Ministry of Finance has issued a document informing that the value-added tax on photovoltaic power generation will be refunded by $50 \%$ immediately, so this part of the preferential VAT reduction policy will be considered when considering the power generation income in the follow-up.

\subsection{Estimation of annual power generation of the project}

The generating capacity is usually related to installed capacity, sunshine hours and system efficiency. The equation is as follows: generating capacity $=$ installed capacity $\times$ sunshine hours $\times$ system efficiency. Among them, the average sunshine in Tongliao City is 4.32 hours/day, and the annual peak sunshine hours are 1576.8 hours (calculated as 365 days a year). The system efficiency is usually between $75 \%$ and $80 \%$. This paper assumes that the efficiency of photovoltaic power generation system is $80 \%$. The installed capacity is 20MW. As the lease period of the project is two and a half years, compared with the equipment, the service period is relatively short. Therefore, this paper does not consider the impact of photovoltaic power generation efficiency attenuation, and calculates the annual power generation of the equipment as follows: $20000 \times 1576.8 \times 80 \%=25228800 \mathrm{KWh}$.

\subsection{Electricity bill estimation}

\subsubsection{Electricity price estimation}

According to the national benchmark price table of desulfurization coal in 2018, the benchmark price of desulfurization in Tongliao City is 0.3035 yuan $/ \mathrm{kWh}$. For photovoltaic power generation enterprises, because they still need to be profitable, this paper will select the electricity price of 0.716 yuan $/ \mathrm{kWh}$ for general industry and commerce according to the electricity price adjustment table issued by the Development and Reform Commission of Inner Mongolia Autonomous Region.

\subsubsection{Subsidy estimation}

Since there is no local policy subsidy in Inner Mongolia, only the state subsidy is considered in the calculation. According to the official information released by the National Development and Reform Commission in 2018, the subsidy standard of distributed electricity price is 0.37 yuan per $\mathrm{kWh}$ (including tax).

\subsubsection{Estimation of power generation income}

The income from photovoltaic power generation mainly consists of the electricity purchase fee offset by the state and local subsidies using self-generated electricity and the surplus electricity sales income, so the power generation income is estimated as follows(5):

$$
E_{t}=S Q_{t}+\partial P_{1} Q_{t}+(1-\partial) P_{2} Q_{t}
$$

Among them, $E_{t}$ stands for power generation income in the first year, $S$ stands for state subsidy, $Q_{t}$ stands for power generation in the first year, $\mathrm{P}_{1}$ stands for local electricity price, $\mathrm{P}_{2}$ stands for Electricity price of desulfurized coal, and represents the proportion of selfused electricity. The estimated annual power generation income is as follows: $0.37 \times 25228800+50 \% \times 0.716 \times 25228800+50 \% \times 0.3035 \times$ $25228800=22195036.8$ (yuan) Quarterly power generation income is RMB5548759.2.

For projects below $10 \mathrm{kw}$, the annual maintenance cost of equipment can be ignored basically, but for 
power plants with initial investment in MW equipment, the maintenance cost has great influence, so it needs to be considered. Operation and maintenance costs generally account for $1 \%-3 \%$ of the initial total investment. [9] This paper assumes that the annual operation and maintenance cost accounts for $2 \%$ of the initial total investment cost, so the annual operation and maintenance cost is $100,000,000 * 1 \%=1,000,000$ yuan, and 250,000 yuan per quarter.

Table 5. Cash flow estimation table of the project within 10 periods of sale and leaseback.

\begin{tabular}{|c|c|c|c|c|c|c|}
\hline Periods & $\begin{array}{c}\text { Initial } \\
\text { cash } \\
\text { inflow } \\
\text { (RMB: } \\
\text { million } \\
\text { ) }\end{array}$ & $\begin{array}{c}\text { Equipment rent } \\
\text { (RMB:yuan) }\end{array}$ & $\begin{array}{c}\text { Operation } \\
\text { and } \\
\text { maintenance } \\
\text { cost } \\
\text { (RMB:yua } \\
\text { n) }\end{array}$ & $\begin{array}{c}\text { Power generation } \\
\text { income (after tax) } \\
\text { (RMB:yuan) }\end{array}$ & $\begin{array}{c}\text { Recover } \\
\text { y price } \\
\text { of } \\
\text { residual } \\
\text { value of } \\
\text { equipme } \\
\text { nt } \\
\text { RMB } \\
\text { :yuan) }\end{array}$ & $\begin{array}{c}\text { Net cash flow } \\
\text { (RMB:yuan) }\end{array}$ \\
\hline $\mathbf{1}$ & +100 & -10743134.59 & -250000 & 3891067.389 & - & 92897932.799 \\
\hline $\mathbf{2}$ & & -10743134.59 & -250000 & 3891067.389 & - & -7102067.201 \\
\hline $\mathbf{3}$ & & -10743134.59 & -250000 & 3891067.389 & - & -7102067.201 \\
\hline $\mathbf{4}$ & & -10743134.59 & -250000 & 3891067.389 & - & -7102067.201 \\
\hline $\mathbf{5}$ & & -10743134.59 & -250000 & 3891067.389 & - & -7102067.201 \\
\hline $\mathbf{6}$ & & -10743134.59 & -250000 & 3891067.389 & - & -7102067.201 \\
\hline $\mathbf{7}$ & & -10743134.59 & -250000 & 3891067.389 & - & -7102067.201 \\
\hline $\mathbf{8}$ & & -10743134.59 & -250000 & 3891067.389 & - & -7102067.201 \\
\hline $\mathbf{9}$ & & -10743134.59 & -250000 & 3891067.389 & - & -7102067.201 \\
\hline $\mathbf{1 0}$ & & -10743134.59 & -250000 & 3891067.389 & -100 & -7102167.201 \\
\hline $\mathbf{1 1}$ & & - & -250000 & 3891067.389 & - & 3641067.389 \\
\hline $\mathbf{1 2}$ & & - & -250000 & 3891067.389 & - & 3641067.389 \\
\hline $\mathbf{1 3}$ & & - & -250000 & 3891067.389 & - & 3641067.389 \\
\hline $\mathbf{1 4}$ & & - & -250000 & 3891067.389 & - & 3641067.389 \\
\hline $\mathbf{1 5}$ & & - & -250000 & 3891067.389 & - & 3641067.389 \\
\hline $\mathbf{1 6}$ & & - & -250000 & 3891067.389 & - & 3641067.389 \\
\hline $\mathbf{1 7}$ & & - & -250000 & 3891067.389 & - & 3641067.389 \\
\hline $\mathbf{1 8}$ & & - & -250000 & 3891067.389 & - & 3641067.389 \\
\hline $\mathbf{1 9}$ & & - & -250000 & 3891067.389 & - & 3641067.389 \\
\hline $\mathbf{2 0}$ & & - & - & & & \\
\hline
\end{tabular}

Through IRR function in Excel software, we can calculate that, assuming that it is calculated according to the 20-year service life of general equipment, we calculate that the embedded return rate of this project is greater than $5 \%$, so the income of this project is greater than the use cost of funds. The scope conditions and formula assumptions set by the rent model in this paper are reasonable to some extent. In the actual project rent pricing game, because the transaction itself has certain flexibility, there is no fixed pricing method, but it is finally determined through the game negotiation between the lessor and the lessee. The lessor's expectation of the rate of return will vary with the fluctuation of market conditions. This paper attempts to limit and calculate the way and range conditions of rent pricing. The rental pricing in the actual project basically accords with the expected income of the lessor. The sale and leaseback provided by financial leasing companies greatly eased the tense situation of financing difficulties of photovoltaic power generation enterprises, and accelerated the rise of photovoltaic industry and the expansion of business segments. Achieve win-win cooperation between new financing methods and emerging industries.
The net cash flow of the project within 20 years can be estimated by considering the equipment rental cash flow expenditure, equipment depreciation, turnover tax, income tax, power generation income and equipment residual value recovery price. Due to the long period of this project and the cumbersome calculation process, this paper intercepts the cash flow of the first 20 periods of the project for the time being, which is shown in Table 5. 
photovoltaic power plants will also be accompanied by certain risks. Power cut and subsidy arrears will lead to unstable cash flow to a certain extent, which will also become one of the important factors for the lessor to consider the project. Therefore, the development of financial leasing projects usually introduces a third party, and takes measures such as objective and independent third-party rating and credit enhancement to prevent the potential risks of the project to a certain extent.

\section{Acknowledgment}

The National Natural Science Foundation of China Grant No.71771076

\section{References}

1. Notice of the National Energy Administration on Matters Related to the Construction of Wind Power and Photovoltaic Power Generation Projects in 2020. (2020)

2. G. Zhou, Y. Qin, J. Risk Leasing and the Development of High-tech Industry in China. Economy and Management. 2002(10):10-11. (2002)

3. Z. Lu, C. Sun, J. Research on the Ways to Solve the Financing Dilemma of High-tech Enterprises from the Perspective of Financial Leasing. Forum on Science and Technology in China. 2014(11):115119. (2014)

4. Z. He, D. Research on Financial Leasing of Industrial Vehicles. (2018)

5. T. Wang, J. Research on Financial Leasing Mode of Photovoltaic Power Plant Industry. Times Finance, 2019(08):78-79. (2019)

6. Y. Cao, D. Research on the Application of Financial Leasing in Photovoltaic Power Generation Enterprises. (2018)

7. Z. Lu, C. Sun, D. Dong, J. Pricing Characteristics and Pricing Effect Evaluation of Financial Leasing Products in China. Operation and management, 26(12):142-148. (2017)

8. J. Xia, D. Research on Financial Leasing Pricing: A Case Study of Civil Aviation Aircraft in China. (2013)

9. J. Shang, D. Dynamic Comprehensive Economic Benefit Analysis of Distributed Photovoltaic. (2020)

10. W. Chen, D. Design of financial leasing scheme for $X$ photovoltaic power generation company. (2018)

11. P. Wang, D. Research on Rent Pricing of Financial Leasing Project of Photovoltaic Power Station. (2017)

12. Y. Huang, D. Study on Financial Leasing Cost of Photovoltaic Power Station and Its Influencing Factors. (2019) 